\title{
Relationship of Leg Muscle Explosion Power and Leg Length to High Jump Ability in Students of Physical Education Study Program Universitas Pendidikan Muhammadiyah Sorong
}

\author{
$1^{\text {st }}$ Risnawati $^{1}, 2^{\text {nd }}$ Jusrianto $^{2}$ \\ \{risnawati@unimudasorong.ac.id ${ }^{1}$, jusrianto@unimudasorong.ac.id ${ }^{2}$ \} \\ Universitas Pendidikan Muhammadiyah Sorong, West Papua, Indonesia
}

\begin{abstract}
Abstrak. This study aims to determine: Is there a relationship between leg muscle explosive power and leg length on the ability to jump high in students of the Physical Education Study Program UNIMUDA Sorong Class of 2018. This research is descriptive with two independent variables and one dependent variable. The population and sample were Sorong Muhammadiyah Education University (UNIMUDA) students. Random sampling was obtained as many as 35 people. The data analysis technique used is Test. Regression (R), in its calculations using the SPSS 20 for Windows program. Significant Level $\alpha=0.05$. Based on the results of data analysis, it was found that there was a significant relationship between leg muscle power and leg length, and high jump ability. (1) There is a significant correlation between leg muscle explosive power and high jump ability where $r=0.210(\mathrm{P}>0.05)$ is obtained, by giving a contribution of $04.40 \%$ (2). There is a significant relationship between leg length and high jump capability where $\mathrm{r}=$ $0.260(\mathrm{P}>0.05)$ is obtained, by giving a contribution of $06.80 \%$ while (3). There is a significant relationship between leg muscle explosive power and leg length on the ability to jump high where the value of $\mathrm{Ro}=0.279(\mathrm{P}>0.05)$, and Fo $=1,350$ with a relationship of $07.80 \%$.
\end{abstract}

Keywords: Leg Muscle Explosion Power, Leg Length, High Jump Ability 


\section{Introduction}

Education is currently very important for the general public, both adults and children. Therefor someone needs to take an education. Education is divided into several parts, namely Formal Education, Non-formal Education, and Informal Education, all of these are very important to achieve a future need. Because it can lead us to the interests of someone in the future. So that education in the east has started to develop and is well known by its citizens but it is still low to be able to understand a learning at the level of Education, therefore, the importance of this eastern society in Indonesia needs an emphasis to increase the interest in learning more extra to be able to understand from in terms of understanding teaching materials that have been given at this Formal Education level.

Learning that is difficult to understand by students, especially in the lecture section with physical education, namely the structure of the physical condition components that play an important role in the branches and numbers in sports. Still lacking and not understanding the function of the components of physical conditions, especially in the physical parts in high jump athletic learning so that in the learning process there are still many students who have not been able to do perfect high jump due to the lack of understanding the ability of physical components, one of which is in the leg muscle power and leg length so there is a need for understanding for students to be able to do high jump athletic numbers better. Where is meant here is the athletic sport is one of the important sports because it contains educational values, and this plays an important role in developing and improving optimal performance in other sports. Where the athletic sports are physical or physical activities that contain natural movements such as walking, running, jumping, rejecting and throwing.

The athletic sport consists of several race numbers in it, namely; run, walk, jump, decline, and throw. All of the race numbers are natural basic movements. So that the focal point in this study is the jump number. The numbers that are often contested are basic movements. One of the athletic numbers that are often contested is the jump number, which consists of long jump, jumpjump, jump high and pole vault. So that the focal point in this study is the high jump number.

Based on observations so far, understanding of high jumps for 2018 Physical Education students has not been very encouraging. this condition is presumed to be due to the physical condition of the existing jumper such as; The leg muscle explosive power and leg length are relatively low and are an obstacle to high jumping skills. High jump motion patterns involve predominantly the whole limbs to run, take-off and cross the crossbar as well as landing. The existence of the running stage, in essence, determines the level of effectiveness of the displayed motion patterns, such as in high jumpers during take-off and stages across the crossbar that is still not good. To achieve maximum learning comprehension on this high jump number, it must be supported by physical abilities. The physical abilities include; Leg muscle explosive power and leg length are very important for maximum jump height. Although the ability of conditions that support high jumping is very much, for this study only utilize the leg muscle explosive power and leg length due to time constraints. 
Ability is owned by everyone but with different capacities. Several people are very good at writing (writing), are quick to understand things, can see the cause of a problem, are skilled at making good things, quickly understand the desires of others, can work together with others, and others. Kreitner (2014: 135) argues that abilities are the responsibility of broad and stable characteristics for one's maximum performance on physical and mental tasks. Another opinion was also expressed by Subkhi (2013: 30) that what is meant by the term capability is one's capacity to carry out several activities in a job. In the opinion of Robbins in Badeni (2013: 13) defines the ability refers to the individual's capacity to perform the various tasks in the job.

Ability includes a broad meaning that is the overall potential possessed by someone to do varies in work. Various abilities possessed by humans, in essence, can be classified into intellectual abilities and physical abilities. Based on the theories of the experts above, it can be concluded that the ability is the overall potential possessed by a person to complete his duties properly regarding his physical and mental tasks. some abilities are brought from birth and some are due to study diligently especially in high jump learning.

A High jump is a form of jumping upward motion by lifting the front leg to bring the highest body weight point and as quickly as possible fall (landing) by repulsion on one foot to reach a certain height.

Explosive power is a combination of strength and speed. To energize the limbs powerfully and quickly in a very short time and provide the best possible momentum to the body. Leg muscle explosive power is very important in every activity in sports, especially those that require the use of limbs, such as high jumping in athletics. Harsono (1988: 199), argues that power is the ability of muscles to overcome resistance to very fast contributions, then Sajoto (1988: 58), argues that explosive power is the ability of a person to exert maximum strength, for his efforts to be mobilized in a short time- in short. Pawers are very important for explosive sports. So that the explosive power of leg muscles is needed in the implementation of high jumps in athletics. The explosive power of leg muscles during running movements or called prefixes is required as well as when taking off before landing.

Leg length is one of the anthropometric measurements, which is the size of the lower limb. The length of the legs is marked by the length of the bones forming the upper limbs and lower limbs, the bones include; femur (os femor), knee bone (os patella), shin bone (os tibia), calf bone (os fibula), ankle bone (ossa torsalia). The femoral patella and tibia joints form knee hinges. The knee is the largest joint of the human body, and although it is relatively strong, it is usually prone to injury due to the complex physical arrangement of the knee because these joints often experience excessive pressure during sports such as sprinting. The proximal end of the tibia forms a rather convex joint surface. Two large femoral condyles are surrounded by a strong arrangement of ligaments and muscles to help the bones absorb the strength when jumping high.

Based on the explanation above, it is known that the relationship between leg muscle power and leg length intended in this study is a naturally developed ability that has not yet received intensive and programmed development and training. The research will be carried out at the Sorong UNIMUDA campus in Kab. Sorong, West Papua, where students have never taken part in an athletics competition in high jump numbers and only got it when they were students. Besides, the problems caused by the Sorong Unimuda Campus are not yet achieving the expected achievements. 


\section{Research Methods}

\subsection{Research Type and Location}

The basic research method is the science of the method or method used to achieve a goal. The method is interpreted as a study of the basic principles of the meaning of investigation which often involves problems about logic, classification, and basic assumptions.

In the description of this research method, issues concerning: identification of variables and research designs, definitions of operational variables, populations and samples, data collection techniques, and data analysis techniques will be raised.

The type of research carried out is a descriptive research type. (Sugiyono 2014: 69) "Correlational Descriptive Research is to find out how much the relationship between independent variables with the dependent variable. And the research location chosen was the Sorong UNIMUDA campus.

\subsection{Variables and Research Design}

\subsubsection{Research variable}

The research variables used in this study include:

a. Independent variable:

- $\quad$ Leg muscle explosion power

- $\quad$ Leg Length

b. Dependent variable:

- $\quad$ High Jump Ability.

The method or method used in this study is a "descriptive" research method with a regression technique. that is, looking for the relationship of one variable with another variable, as for the simple correlation research design used is the "Regression Method".

\subsubsection{Definition of Operational Research Variables}

Research variables that need to be defined operationally include:

a. Harsono (1988: 199), argues that power is the ability of muscles to overcome resistance to contributions that are very fast, then Sajoto (1988: 58), argues that explosive power is a person's ability to exert maximum strength, in the effort that is mobilized in time as short as possible.

b. Leg length is one anthropometric measure that is the size of the lower limb. Leg length is characterized by the length of the bones forming the upper limbs and lower limbs. To find out the length of the limbs by measuring from the heel to the person's hips.

c. A high jump is a form of jumping upward motion by lifting the front leg to bring the highest body weight point possible and as quickly as possible fall (landing) by performing repulsion on one foot to reach a certain height.

\subsection{Population and Sample}

\subsubsection{Population}


The population is a generalization area that consists of: objects/subjects that have certain qualities and characteristics determined by researchers to be studied and then drawn sugiyono conclusions (2014: 117)

So the population is not only people but also objects and other natural objects. The population is also not only the amount that exists on the object/subject studied but includes all characteristics/properties possessed by the subject or object.

One factor that determines the smoothness to obtain data with research is the population. The population of this research is all students of study programs. Physical UNIMUDA Sorong class of 2018

Table 1. Total population of Student Physical UNIMUDA Sorong of 2018

\begin{tabular}{|l|c|c|c|}
\hline Class & Male & Female & Amount \\
\hline Class A & 16 & 8 & 24 \\
\hline Class B & 19 & 6 & 25 \\
\hline Class C & 20 & 5 & 25 \\
\hline Class D & 17 & 4 & 21 \\
\hline Amount & 72 & 23 & 95 \\
\hline Total Population & \multicolumn{4}{|c|}{95} \\
\hline
\end{tabular}

Information:

Class A: 2018 class one

Class B: Semester one class of 2018

Class C: 2018 class one semester

Class D: Semester one class of 2018

\subsubsection{Samples}

The sample is simply interpreted as a portion of the population that is used as the actual data source. (Sugiyono: 2014: 118), stated that: The sample is part of the number of characteristics owned by the population. The sample used in this study were 35 male students by using a total sampling by taking the entire number of the population of 72 male students who were obtained in the study program Physical Education force of 2018.

\subsection{Data collection technique}

To obtain empirical data as material to test the truth of hypotheses, data collection is based on the variables involved.

\subsection{Data analysis technique}

Data collected through tests are still rough data. The data is then analyzed using statistical regression tests with the help of SPSS packages on the computer.

The analysis referred to in this study is descriptive analysis, and inferential. Descriptive analysis to describe the data as it is. Whereas the infra-analysis to test hypotheses using simple regression analysis and multiple regression analysis. Before using the formula, normality analysis is first performed using the Kolmogorov Smirnov (KS-Z) technique with the SPSS program on a computer. 


\section{Research Results}

\subsection{Presentation of data analysis results}

Empirical data obtained in the field in the form of test and measurement results consisting of leg muscle explosive power and leg length on high jumping ability in students of the physical education study program in Sorong UNIMUDA class of 2018 were first held data tabulation to facilitate further testing. Analysis of the data used in this study was analyzed by statistical techniques.

\subsection{Descriptive analysis}

The following are the results of the descriptive analysis of leg muscle power and leg length explosive data on high jumping ability.

- Leg muscle power explosion obtained an average value of 78.66, standard deviation 4.31, minimum value 69 , max maximum value 87 , range 18 , sum value 2753 , variance value 18.59 .

- Leg Length obtained an average value of 85.91, the standard deviation of 6.026, a minimum value of 74, a maximum value of 95, range 21, the sum value of 3007, variance value of 6.03.

- High Jump Ability, obtained an average value of 1.62, a standard deviation of 14.61, a minimum value of 130 , a maximum value of 182 , a range of 52, a sum of 5657, a variance value of 213.36 .

\subsection{Data Normality Test}

To find out whether the leg muscle explosive power data and leg length on the High Jump Ability in Students of the Physical Education Study Program UNIMUDA Sorong Class of 2018 has a normal or abnormal distribution, then testing is done using the Kolmogorov Smirnov test.

It is obtained that the data normality test using the Kolmogorov-Smirnov test shows the following results:

- Tungka Muscle Explosion Power obtained KS-Z value $=0.576(\mathrm{P}>0.05)$, then these results indicate that the data on the Leg Muscle Explosion Power follows a normal distribution or normal distribution.

- $\quad$ Leg Length obtained KS-Z value $=0.766(\mathrm{P}>0.05)$, so this shows that the Length Length data follows a normal distribution or normal distribution.

- High Jump Ability is obtained KS-Z value =0.764 $(\mathrm{P}>0.05)$, then this shows that the High Jump Ability data follows a normal distribution or normal distribution.

\subsection{Regression analysis}

a. There is a significant relationship between leg muscle explosive power and high jump ability among students of the Physical Education Study Program at UNIMUDA Sorong, class of 2018 , which is $04.40 \%$.

b. There is a significant relationship between limb length and high jump ability among students of the physical education study program at UNIMUDA Sorong, 2018, amounting to $06.80 \%$.

c. There was a significant correlation between leg muscle explosive power and leg length on the ability to jump high in students of the Physical Education Study Program at UNIMUDA Sorong, class of 2018 , amounting to $07.80 \%$. 


\section{Discussion}

a. There is a significant relationship between leg muscle explosive power and high jump ability among students of the Physical Education Study Program at UNIMUDA Sorong, class of 2018

The results of statistical analysis show that there is a significant relationship between leg muscle explosive power and high jumping ability in students of the UNIMUDA Physical Education study program, Sorong class of 2018. If the results of this study are related to the theory and underlying mindset, then basically the results of this study support and strengthen theories and results of previous research that already exist. Because it states that power is the ability of muscles to overcome resistance to very fast contributions, then Sajoto (1988: 58), argues that explosive power is the ability of a person to exert maximum strength, for his efforts to be mobilized in the shortest possible time, it can be seen in the process of high jumping movements. makes a student can make high jump movements with as fast as the effort in the shortest possible time. If the leg muscle explosive power is analyzed from the process of motion involved in it, then the leg muscle explosive element supports the high jump ability of students of the Physical Education Study Program at UNIMUDA Sorong class of 2018. Students who have high and strong leg muscle explosive power will naturally be able to make movements jump high well. In this case, the leg muscle explosive power contributes a significant $04.40 \%$ to the student making a high jump.

b. There is a significant relationship of limb length to the ability of high limpet in the students of the Physical Education study program in Sorong UNIMUDA class of 2018.

The results of the variable analysis show that there is a significant relationship between leg length and high jump ability among students of the UNIMUDA Physical Education Study Program Sorong class of 2018. If the results of this study are related to the theory and framework of the underlying variables, then basically the results of this study support and strengthen the theory and the results of previous studies that already exist. students who have long limbs, then these students can make fast movements or have the fast acceleration to push the body forward or bring the body forward quickly. Because the length of the leg is one anthropometric measure that is the size of the lower limb. The length of the legs is marked by the length of the bones forming the upper limbs and lower limbs, the bones include; femur (os femor), knee bone (os patella), shin bone (os tibia), calf bone (os fibula), ankle bone (ossa torsalia), it can be seen in the process of high jump movements. makes a student can make high jump movements quickly effort in the shortest possible time. If the leg length is analyzed from the process of motion involved in it, then the element of leg length supports the ability to jump high on students of the UNIMUDA Physical Education Study Program Sorong class of 2018. Students who have high and strong leg length will naturally be able to make fast and precise high jump movements. In this case, the length of the leg contributes a significant amount of $06.80 \%$ to the student making a high jump.

c. There is a significant correlation together with leg muscle explosive power and leg length on the students of the UNIMUDA Physical Education Study Program, Sorong class of 2018. 
The results of the variable analysis show that there is a significant relationship together with the leg muscle explosive power and leg length on the students of the UNIMUDA Physical Education Study Program Sorong class of 2018. If the results of this study are linked to the theory and framework of the underlying variables, basically the results of this study support and strengthen existing theories. If students have variable leg muscle explosive power and leg length together in good conditions will be able to do the whole series in the implementation of high jump movements. This can be seen by the amount of contribution made by the two independent variables together at $07.80 \%$

\section{CONCLUSION}

Based on data analysis and discussion, the results of this study can be concluded as follows:

a. There is a significant relationship with leg muscle power explosion

b. high jumping ability in students of the UNIMUDA Physical Education Study Program Sorong class of 2018 .

c. There is a significant relationship between leg length and high jump ability among students of the Physical Education Study Program, UNIMUDA Sorong, class of 2018.

d. There is a significant joint relationship between the total leg power and leg length to the high jump ability of students of the SIMU Physical Education Study Program 2018.

\section{References}

[1] Arikunto, S. (1991). Prosedur Penelitian Suatu Pendekatan Praktek, Jakarta.

[2] Dahara Prize, (1988). Peningkatan dan Pembinaan Kondisi Fisik. Semarang: IKIP Semarang

[3] Depdikbud, (1989). Kamus Besar Bahasa Indonesia. Jakarta: Balai Pustaka.

[4] Dikdik Zafar Sidik, 2014. Mengajar dan Melatih Atletik. PT Remaja Rosdakarya. Bandung.

[5] Harsono, (1988). Coaching dan Aspek Psikologi Dalam Coaching. Dirjen Dikti: Jakarta.

[6] Jess Jarver, 2014.Belajar dan Berlatih Atletik. Pionir Jaya. Bandung.

[7] Munasifah, Atletik Cabang Lompat. Aneka Ilmu.Semarang.

[8] M. Sajoto, (1995). Peningkatan dan Pembinaan Kekuatan Kondisi Fisik Dalam Olahraga. Semarang

[9] Radioputro, (1991). Kinesiologi dan Body Mechanies. Dirjen Pemuda dan Olahraga Depdikbuk Jakarta

[10]Risnawati, (2016). Hubungan Panjang Tungkai, Frekuensi Langkah Kaki dan Kelentukan Terhadap Kecepatan Lari 50 Meter Siswa SMA Negeri 1 Tompobulu Kab. Bantaeng. UNM: Makassar. 